University of Nebraska - Lincoln

DigitalCommons@University of Nebraska - Lincoln

Faculty Papers and Publications in Animal

Science

Animal Science Department

4-26-1995

\title{
Prediction of Genetic Values of Sires for Growth Traits of Crossbred Cattle Using a Multivariate Animal Model with Heterogeneous Variances
}

\author{
R. Nunez-Dominguez \\ University of Nebraska-Lincoln, rafael.nunez@correo.chapingo.mx \\ L. Dale Van Vleck \\ University of Nebraska-Lincoln, dvan-vleck1@unl.edu \\ Larry V. Cundiff \\ University of Nebraska-Lincoln, Icundiff2@unl.edu
}

Follow this and additional works at: https://digitalcommons.unl.edu/animalscifacpub

Part of the Animal Sciences Commons

Nunez-Dominguez, R.; Van Vleck, L. Dale; and Cundiff, Larry V., "Prediction of Genetic Values of Sires for Growth Traits of Crossbred Cattle Using a Multivariate Animal Model with Heterogeneous Variances" (1995). Faculty Papers and Publications in Animal Science. 261.

https://digitalcommons.unl.edu/animalscifacpub/261

This Article is brought to you for free and open access by the Animal Science Department at DigitalCommons@University of Nebraska - Lincoln. It has been accepted for inclusion in Faculty Papers and Publications in Animal Science by an authorized administrator of DigitalCommons@University of Nebraska - Lincoln. 


\title{
Prediction of Genetic Values of Sires for Growth Traits of Crossbred Cattle Using a Multivariate Animal Model with Heterogeneous Variances ${ }^{1}$
}

\author{
R. Núñez-Dominguez*, L. D. Van Vleck ${ }^{\dagger}, *$, and L. V. Cundifft \\ ${ }^{\dagger}$ Roman L. Hruska U.S. Meat Animal Research Center, ARS, USDA, Clay Center, NE 68933 and \\ *Department of Animal Sciences, University of Nebraska, Lincoln 68583-0908
}

\begin{abstract}
The purpose of this study was to evaluate the effect of adjusting for heterogeneous variances across breed groups on prediction of breeding values (PBV) of selected sires and on breed of sire effects. Data on weights at birth (BWT), $200 \mathrm{~d}$ (WW), and $365 \mathrm{~d}$ (YW) of purebred and crossbred calves from matings of Angus $(A)$, Hereford $(H)$, Polled Hereford, Charolais, Shorthorn, Simmental, Limousin, Maine-Anjou, Chianina, Gelbvieh, Tarentaise, and Salers bulls to $A$ and $H$ cows were used. Calf performance in $\mathrm{H}$ and $\mathrm{A}$ dams was treated as a different trait. Models compared included fixed birth year, cow age, and sex classes and crossbreeding effect as a covariate; random direct and maternal genetic and permanent environmental effects were also included, but their variance structure was different. Model I assumed homogeneous variances across breed groups. Model II accounted for heterogeneous variances. Sires were ranked based on PBV from each
\end{abstract}

model, and means of PBV of selected sires were calculated based on Model II. Differences between mean PBV were small for BWT, intermediate for WW, and larger for YW. Differences in PBV of selected sires increased as selection intensity increased, but only for WW and YW. Large differences in mean PBV of selected sires between maternal environments ( $H$ vs A) were observed for WW and YW for various sire breeds. Means of PBV of selected sires based on Model II exceeded those based on Model I by 6 to $16 \mathrm{~kg}$ of YW for various selection intensities and maternal environments. Estimates of breed of sire effects from Model I or II were similar for BWT and WW, but large differences were found for $\mathrm{YW}$. Results indicate that some additional economic returns may be gained by commercial producers if sires are chosen across breeds based on predicted genetic values computed with models accounting for heterogeneous variances.

Key Words: Breeding Values, Growth Traits, Heterogeneity, Beef Cattle, Multivariate Analysis

J. Anim. Sci. 1995. 73:2940-2950

\section{Introduction}

Currently, interest has increased about the possibility of comparing genetic values of bulls across breeds of beef cattle to take advantage of genetic differences within and among breeds (e.g., BIF, 1989, 1991). When the genetic evaluation of sires from various breeds mated to different breeds of dams is desired, information about sire $\times$ breed of dam interaction and about heterogeneity of variances across breed groups is required. Indications of reranking of sires when mated to different breeds of dams have been previously reported (Massey and Benyshek, 1981; Tilsch et al., 1989; Núñez-Dominguez et al., 1993a). Although

\footnotetext{
${ }^{1}$ Published as paper no. 10661, J ournal Ser., Nebraska Agric. Res. Div., Univ. of Nebraska, Lincoln.

Received March 21, 1994.

Accepted April 26, 1995.
}

the assumption of homogeneous variances is reasonable for data on purebreds, when different breed groups are involved in genetic evaluations this assumption may no longer be true (EIzo and Famula, 1985; Van Vleck, 1987; Arnold et al., 1992), as evidence in beef cattle suggests (Garrick et al., 1989; Núñez-Dominguez et al., 1993a).

Procedures to handle heterogeneous variances across genetic groups in beef cattle have been developed by Elzo and Famula (1985) using sire-maternal grandsire models and by Arnold et al. (1992) using an animal model or a reduced animal model. However, effects of adjusting for heterogeneous variances of various random effects have not been reported. Thus, the purpose of this study is to evaluate the importance of accounting for heterogeneity of variances across genetic groups on prediction of genetic values of selected sires and on estimates of breed of sire effects using a multivariate animal model. 


\section{Materials and Methods}

Description of Data. Records of birth weight ( BWT, $\mathrm{n}=5,137$ ), 200-d weight ( $\mathbf{W} \mathbf{W}, \mathrm{n}=4,744$ ), 365-d weight ( $\mathbf{Y W}, \mathrm{n}=4,474$ ) of purebred and crossbred calves produced in the Germplasm Evaluation (GPE) Program at the Roman L. Hruska U.S. Meat Animal Research Center in Clay Center, NE were used. Matings of sires of several breeds to Hereford and Angus cows have been made in the GPE program to characterize breed resources for many economically important traits. F our cycles of the GPE project have been completed. Cycle I was conducted from 1970 through 1972, Cycle II in 1973 and 1974, Cycle III in 1975 and 1976, and Cycle IV from 1986 through 1990. Twelve breeds were used in this study: Angus, Hereford, and Polled Hereford in all cycles; Charolais in cycles I and IV; Limousin and Simmental in Cycle I; Gelbvieh, Maine-Anjou, and Chianina in Cycle II; Tarentaise in Cycle III; and Shorthorn and Salers in Cycle IV. The same Hereford, Angus, and Polled Hereford bulls were used by artificial insemination in all cycles to create ties for breed comparisons. Additionally, new samples of Hereford, Angus, Polled Hereford, and Charolais bulls born after 1982 were used in Cycle IV.

Numbers of sires across the 12 sire breeds were 393, 390, and 388 for BWT, WW, and YW, respectively. Calf performance in Hereford or Angus maternal environments was treated as a different trait. Numbers of calves out of Hereford and Angus cows were, respectively, 2,387 and 2,750 for BWT, 2,180 and 2,564 for WW, and 2,092 and 2,382 for YW. More information about numbers of sires, dams, and progeny by breed of sire and breed of dam was reported in a previous paper ( $\mathrm{N}$ úñez-Dominguez et al., 1993a).

Management of these animals has been reported (e.g., Smith et al., 1976; Laster et al., 1979; Cundiff et al., 1984). In brief, calves were born in the spring, males were castrated within $24 \mathrm{~h}$ and all calves were weaned at about $200 \mathrm{~d}$ of age, except that calves born in 1974 were weaned at $167 \mathrm{~d}$ of age due to drought conditions. After weaning, heifers were managed to calve at $2 \mathrm{yr}$ of age and were fed a diet of approximately $50 \%$ corn silage and $50 \%$ alfalfa or grass haylage, plus protein and mineral supplement. Steers received a high-energy-density diet for approximately $196 \mathrm{~d}$, after a preconditioning period of 25 to $58 \mathrm{~d}$. Averaged across years and feeding periods the diets contained (dry matter basis) approximately $12.8 \%$ crude protein, $9.2 \%$ digestible protein, and 2.8 $\mathrm{Mcal}$ of $\mathrm{ME} / \mathrm{kg}$.

The Model. Two models with similar fixed and random effects but with different covariance structures were compared. Both models account for reranking of sire's breeding values across Hereford and Angus maternal environments by treating perfor- mance of calves of each of these breeds of dams as a different trait. The model for traits (e.g., birth weight) expressed in Hereford or Angus maternal environments, $\mathbf{h}$ or $\mathbf{a}$, respectively, can be represented as follows:

$$
\begin{gathered}
{\left[\begin{array}{l}
y_{h} \\
y_{a}
\end{array}\right]=\left[\begin{array}{ll}
X_{h} & 0 \\
0 & X_{a}
\end{array}\right]\left[\begin{array}{l}
b_{h} \\
b_{a}
\end{array}\right]+\left[\begin{array}{ll}
T_{h} & 0 \\
0 & T_{a}
\end{array}\right]\left[\begin{array}{l}
t_{h} \\
t_{a}
\end{array}\right]} \\
+\left[\begin{array}{ll}
Z_{h} & 0 \\
0 & Z_{a}
\end{array}\right]\left[\begin{array}{l}
g_{h} \\
g_{a}
\end{array}\right]+\left[\begin{array}{ll}
M_{h} & 0 \\
0 & M_{a}
\end{array}\right]\left[\begin{array}{l}
m_{h} \\
m_{a}
\end{array}\right] \\
+\left[\begin{array}{ll}
W_{h} & 0 \\
0 & W_{a}
\end{array}\right]\left[\begin{array}{l}
p_{h} \\
p_{a}
\end{array}\right]+\left[\begin{array}{l}
e_{h} \\
e_{a}
\end{array}\right]
\end{gathered}
$$

The representation when both traits are combined is as follows:

$$
\mathbf{y}=\mathbf{X b}+\mathbf{T t}+\mathbf{Z g}+\mathbf{M m}+\mathbf{W p}+\mathbf{e},
$$

where $\mathbf{y}$ is the vector of observations; $\mathbf{b}$ is the vector of common fixed effects across sire breeds (but separate for each breed of dam) including birth year, cow age, and sex as classes, and the crossbreeding (HET) effect as a covariate; $\mathbf{X}$ is the matrix that associates $\mathbf{b}$ with $\mathbf{y} ; \mathbf{t}$ is the vector of sire-breed effects or sire breed-group effects (sires from Angus, Hereford, Polled Hereford, and Charolais breeds were assigned to two groups corresponding to bulls born before or after 1982, for example, Angus 1 and Angus 2); $\mathbf{T}$ is the matrix that associates $\mathbf{t}$ with $\mathbf{y} ; \mathbf{g}$ is the vector of breeding values for direct genetic effects; $\mathbf{Z}$ is the matrix that associates $\mathbf{g}$ with $\mathbf{y} ; \mathbf{m}$ is the vector of breeding values for maternal genetic effects; $\mathbf{M}$ is the matrix that associates $\mathbf{m}$ with $\mathbf{y} ; \mathbf{p}$ is the vector of permanent environmental effects including nonadditive genetic effects contributed by dams to their progeny; $\mathbf{W}$ is the matrix that associates $\mathbf{p}$ with $\mathbf{y}$; and $\mathbf{e}$ is the vector of residual effects that are not explained by other parts of the model. Birth date was included in $\mathbf{b}$ as a covariate for BWT but not for WW or YW. Expectations of these models are as follows:

$$
\mathbf{E}[\mathbf{y}]=\mathbf{X b}+\mathbf{T t}
$$

The difference between the models was the covariance structure assumed. Model I, the average variance model, assumed homogeneous variances and covariances across all sire breeds. Thus, averages of the estimates of (co)variance components by sire breed (Tables 1, 2, and 3) were obtained to use in setting up the mixed-model equations. These (co)variance components were estimated by Núñez-Dominguez et al. (1993a). The variance-covariance matrix of genetic effects is $\mathbf{G}=\mathbf{G}_{0} \cdot \mathbf{A}$, where $\mathbf{A}$ is the matrix of additive genetic relationships among animals, · is a direct product operator, and $\mathbf{G}_{0}$ is the matrix of (co)variances between traits of an animal: 
Table 1. Estimates of variances for direct $\left(\sigma_{\mathrm{g}}^{2}\right)$ and maternal $\left(\sigma_{\mathrm{m}}^{2}\right)$ genetic effects and for permanent environmental $\left(\sigma_{\mathrm{p}}^{2}\right)$ and residual $\left(\sigma_{\mathrm{e}}^{2}\right)$ effects, and of covariances $\left(\sigma_{\mathrm{gm}}\right)$ between $\mathrm{g}$ and $\mathrm{m}$, for expression of genes in calves from Hereford $(\mathrm{H})$ and Angus (A) cows for birth weight

\begin{tabular}{|c|c|c|c|c|c|c|c|c|c|c|c|}
\hline Breed & $\sigma_{g}^{2}(\mathrm{H})$ & $\sigma_{\mathrm{g}}^{2}(\mathrm{~A})$ & $\sigma_{\mathrm{m}}^{2}(\mathrm{~A})$ & $\sigma_{\mathrm{m}}^{2}(\mathrm{~A})$ & $\sigma_{p}^{2}(H)$ & $\sigma_{\mathrm{p}}^{2}(\mathrm{~A})$ & $\sigma_{\mathrm{e}}^{2}(\mathrm{H})$ & $\sigma_{\mathrm{e}}^{2}(\mathrm{~A})$ & $\sigma_{\mathrm{g}}(\mathrm{H}, \mathrm{A})$ & $\sigma_{\mathrm{gm}}(\mathrm{H})$ & $\sigma_{\mathrm{gm}}(\mathrm{A})$ \\
\hline Angus & 10.08 & 10.79 & 1.83 & .15 & .54 & 4.00 & 3.53 & 2.99 & 9.55 & .01 & -.48 \\
\hline Hereford & 12.47 & 7.92 & 3.43 & 3.26 & .01 & .02 & 3.38 & 8.39 & 9.66 & 1.42 & -.46 \\
\hline Charolais & 12.03 & 10.53 & 8.51 & 2.57 & 1.01 & 7.87 & 3.12 & .95 & 10.40 & -1.26 & 1.89 \\
\hline Shorthorn & 13.48 & 9.02 & 6.20 & .83 & 1.93 & 3.78 & 6.99 & 7.53 & 4.23 & 4.86 & 2.23 \\
\hline Simmental & 6.75 & 8.93 & .54 & 5.44 & .60 & .48 & 14.12 & 2.43 & 7.32 & -.15 & 2.25 \\
\hline Chianina & 14.65 & 14.12 & 2.51 & 11.17 & 1.88 & 1.56 & 7.87 & 3.45 & 14.21 & .37 & 1.07 \\
\hline Gelbvieh & 14.86 & 12.64 & 5.58 & 4.89 & 2.87 & 1.72 & .81 & 6.98 & 13.00 & .02 & -2.43 \\
\hline Tarentaise & 6.37 & 2.61 & 5.98 & .45 & 3.71 & .71 & .38 & 12.33 & 3.52 & 1.25 & .51 \\
\hline Salers & 2.26 & 3.49 & 1.28 & 12.02 & 16.59 & 4.07 & 2.21 & 6.20 & 2.60 & -.01 & -2.39 \\
\hline Average & 10.88 & 9.13 & 3.50 & 3.65 & 1.84 & 2.31 & 3.78 & 5.14 & 8.83 & .65 & .43 \\
\hline
\end{tabular}

Table 2. Estimates of variances for direct $\left(\sigma_{\mathrm{g}}^{2}\right)$ and maternal $\left(\sigma_{\mathrm{m}}^{2}\right)$ genetic effects and for permanent environmental $\left(\sigma_{\mathrm{p}}^{2}\right)$ and residual $\left(\sigma_{\mathrm{e}}^{2}\right)$ effects, and of covariances $\left(\sigma_{\mathrm{gm}}\right)$ between $\mathrm{g}$ and $\mathrm{m}$, for expression of genes in calves from Hereford $(\mathrm{H})$ and Angus (A) cows for 200-day weight

\begin{tabular}{|c|c|c|c|c|c|c|c|c|c|c|c|}
\hline Breed & $\sigma_{\mathrm{g}}^{2}(\mathrm{H})$ & $\sigma_{\mathrm{g}}^{2}(\mathrm{~A})$ & $\sigma_{\mathrm{m}}^{2}(\mathrm{H})$ & $\sigma_{\mathrm{m}}^{2}(\mathrm{~A})$ & $\sigma_{p}^{2}(H)$ & $\sigma_{\mathrm{p}}^{2}(\mathrm{~A})$ & $\sigma_{\mathrm{e}}^{2}(\mathrm{H})$ & $\sigma_{\mathrm{e}}^{2}(\mathrm{~A})$ & $\sigma_{g}(\mathrm{H}, \mathrm{A})$ & $\sigma_{\mathrm{gm}}(\mathrm{H})$ & $\sigma_{\mathrm{gm}}(\mathrm{A})$ \\
\hline Angus & 310.5 & 231.3 & 173.8 & 96.5 & .1 & 49.9 & 75.1 & 48.1 & 253.0 & 51.3 & 37.5 \\
\hline Hereford & 133.4 & 193.3 & 136.3 & 207.2 & .1 & 22.1 & 177.6 & 126.5 & 88.7 & 85.2 & -76.3 \\
\hline Polled Hereford & 302.1 & 221.1 & 146.1 & 9.0 & 159.2 & 88.8 & 22.8 & 120.1 & 198.8 & 37.0 & 24.3 \\
\hline Charolais & 274.7 & 96.6 & 279.6 & 78.8 & 8.7 & 10.3 & 176.6 & 307.8 & 88.4 & 83.8 & 46.9 \\
\hline Shorthorn & 205.3 & 211.6 & 269.1 & 8.7 & 57.8 & 7.4 & 70.0 & 370.8 & 196.9 & 55.4 & -3.2 \\
\hline Simmental & 179.6 & 247.9 & 55.1 & 124.4 & 55.1 & 165.6 & 65.1 & 14.3 & 151.1 & 46.1 & -103.4 \\
\hline Limousin & 247.1 & 293.8 & 77.8 & 186.0 & 106.6 & 28.7 & 82.1 & 102.4 & 178.0 & 95.9 & 67.5 \\
\hline Maine-Anjou & 291.7 & 204.3 & 88.4 & 84.9 & 12.6 & 116.6 & 238.2 & 102.5 & 136.5 & 68.3 & 67.0 \\
\hline Chianina & 256.4 & 267.8 & 154.1 & 285.1 & 63.2 & 10.9 & 36.5 & 10.8 & 192.8 & 67.6 & 63.7 \\
\hline Gelbvieh & 174.5 & 95.6 & 19.3 & 1.0 & 344.8 & 98.6 & 198.0 & 252.4 & 118.4 & -22.1 & -.3 \\
\hline Tarentaise & 303.5 & 277.0 & 141.6 & 127.6 & 83.6 & 8.0 & 98.1 & 79.8 & 237.6 & 84.1 & 81.4 \\
\hline Salers & 319.6 & 101.7 & 133.7 & 340.6 & 129.5 & 6.6 & 149.8 & 4.9 & 170.5 & 55.0 & 35.8 \\
\hline Average & 248.5 & 201.2 & 147.6 & 128.3 & 59.4 & 49.4 & 115.4 & 125.5 & 165.6 & 59.7 & 5.1 \\
\hline
\end{tabular}

Table 3. Estimates of variances for direct $\left(\sigma_{\mathrm{g}}^{2}\right)$ and maternal $\left(\sigma_{\mathrm{m}}^{2}\right)$ genetic effects and for permanent environmental $\left(\sigma_{\mathrm{p}}^{2}\right)$ and residual $\left(\sigma_{\mathrm{e}}^{2}\right)$ effects, and of covariances $\left(\sigma_{\mathrm{gm}}\right)$ between $\mathrm{g}$ and $\mathrm{m}$, for expression of genes in calves from Hereford $(\mathrm{H})$ and Angus (A) cows for 365-day weight

\begin{tabular}{|c|c|c|c|c|c|c|c|c|c|c|c|}
\hline Angus & 493.3 & 702.9 & 233.8 & 177.4 & 16.4 & 42.4 & 242.7 & 205.5 & 397.3 & 199.6 & 134.0 \\
\hline Polled Hereford & 638.1 & 355.7 & 470.2 & 113.4 & 35.6 & 130.9 & 411.3 & 215.4 & 383.1 & 242.7 & -88.7 \\
\hline Charolais & 544.0 & 800.5 & 22.6 & 16.3 & 433.4 & .1 & 241.5 & 367.6 & 649.1 & 15.6 & 12.9 \\
\hline Shorthorn & 213.3 & 209.9 & 20.0 & 125.4 & 877.1 & 96.6 & 321.5 & 859.5 & 183.9 & 22.9 & -60.3 \\
\hline Simmental & 522.0 & 492.8 & 100.6 & 85.2 & .1 & 203.1 & 42.5 & 306.9 & 442.0 & 112.0 & -8.6 \\
\hline Chianina & 214.2 & 661.3 & 485.0 & 145.1 & 156.7 & 2.9 & 30.3 & 74.2 & 366.0 & 38.7 & -.9 \\
\hline Gelbvieh & 781.1 & 725.9 & 359.6 & 510.7 & .1 & .1 & 224.5 & .1 & 694.6 & 180.1 & -115.7 \\
\hline Tarentaise & 278.9 & 160.6 & 56.0 & 25.6 & 94.1 & 78.8 & 126.4 & 455.7 & 125.2 & 38.6 & 28.1 \\
\hline Salers & 280.3 & 307.0 & 373.2 & 170.7 & 261.7 & 156.4 & 507.5 & 127.0 & 225.5 & 200.9 & 37.7 \\
\hline Average & 491.9 & 559.9 & 208.8 & 172.7 & 205.2 & 46.3 & 184.1 & 224.7 & 427.6 & 112.4 & 66.1 \\
\hline
\end{tabular}




$$
\mathrm{G}_{\mathrm{o}}=\left[\begin{array}{llll}
\sigma_{\mathrm{g}_{\mathrm{h}}}^{2} & \sigma_{\mathrm{g}_{\mathrm{ha}}} & \sigma_{\mathrm{gm}_{\mathrm{h}}} & 0 \\
\sigma_{\mathrm{g}_{\mathrm{ha}}} & \sigma_{\mathrm{g}_{\mathrm{a}}}^{2} & 0 & \sigma_{\mathrm{gm}_{\mathrm{a}}} \\
\sigma_{\mathrm{gm}_{\mathrm{h}}} & 0 & \sigma_{\mathrm{m}_{\mathrm{h}}}^{2} & 0 \\
0 & \sigma_{\mathrm{gm}_{\mathrm{a}}} & 0 & \sigma_{\mathrm{m}_{\mathrm{a}}}^{2}
\end{array}\right] .
$$

The diagonal variance matrix of maternal permanent environmental effects is $\mathbf{P}$ of order equal to the number of dams, with diagonals $\boldsymbol{\sigma}_{\mathrm{pi}}^{2}$ for $\mathbf{i}=\mathbf{h}, \mathbf{a}$. The diagonal variance matrix of residual effects is $\mathbf{R}$ of order equal to the number of records, with diagonals $\boldsymbol{\sigma}_{\mathrm{ei}}^{2}$ for $\mathbf{i}=\mathbf{h}, \mathbf{a}$.

Except for the g's and m's within breed of dam, all random effects are assumed to be uncorrelated. The reason is that although maternal effects could be estimated for Hereford and Angus sires through the relationship matrix, this could not be done for all other breeds, because they did not have any $F_{1}$ daughters used as dams in the data set.

Inverses of the variance-covariance matrices for random effects are required to set up the mixed-model equations. The inverse of the variance-covariance matrix of genetic effects is $\mathbf{G}^{-1}=\mathbf{G}_{\mathrm{o}}^{-1} \cdot \mathbf{A}^{-1}$, which can be represented as follows:

$$
\mathrm{G}^{-1}=\left[\begin{array}{cc}
G^{g} & \mathrm{G}^{\mathrm{gm}} \\
\mathrm{Ggm}^{\mathrm{gm}} & \mathrm{G}^{\mathrm{m}}
\end{array}\right] \text {, }
$$

where, for example, $\mathbf{G} 9$ is the direct product of the first $2 \times 2$ diagonal block of $\mathbf{G}_{0}^{-1}$ by $\mathbf{A}^{-1}$; then, the left-hand side ( LHS) of the mixed-model equations, augmented by zero columns in $\mathbf{Z}$ and $\mathbf{M}$ so that $\mathbf{g}$ and $\mathbf{m}$ contain the same animals, can be written as follows:

$$
\left.\begin{array}{ll}
X^{\prime} R^{-1} M & X^{\prime} R^{-1} W \\
T^{\prime} R^{-1} M & T^{\prime} R^{-1} W \\
Z^{\prime} R^{-1} M+G g m & Z^{\prime} R^{-1} W \\
M^{\prime} R^{-1} M+G^{m} & M^{\prime} R^{-1} W \\
W^{\prime} R^{-1} M & W^{\prime} R^{-1} W+P^{-1}
\end{array}\right]
$$

Analyses with model I were done using a multipletrait derivative-free REML program (Boldman et al., 1993). Solutions for fixed and random effects and expectations of the solutions for fixed effects were obtained.

Model II, the heterogeneous variance model, accounts for heterogeneous variances across sire breeds. Separate estimates of (co)variance components ( $\mathrm{Ta}$ bles 1, 2, and 3) by breed of sire were used to set up the mixed-model equations. The procedure under this model was the following: 1) Separate analyses by each breed of sire, using the multiple-trait program already mentioned, were done to obtain equation numbers and respective coefficients of the LHS and right-hand side ( R HS) of the mixed-model equations for each breed of sire. 2) Equation numbers of the LHS and RHS for common fixed effects across sire breeds were recoded to be the same for all separate analyses. 3) The recoded LHS and RHS members from separate analyses were combined and then used with SPARSPAK, a sparse matrix software package (George et al., 1980), to obtain solutions, sampling variances, and expectations.

The structure of the LHS of the mixed-model equations are analogous to the LHS under Model I, but with a series of 12 diagonal blocks corresponding to each breed of sire. Each block includes breed group of sire effects and genetic and permanent environmental effects.

Among these two models, the one accounting for heterogeneous variances, or Model II, was chosen as the more correct model. For these models, predictions of breeding values of sires are the sum of solutions for sire group effects and solutions for deviations due to direct genetic effects. Breeding values of sires for each performance trait were predicted under each of the two models when sires would be mated to Hereford ( $\hat{\mathbf{t}}_{\mathbf{i}}$ $\left.+\hat{\mathbf{g}}_{\mathrm{ij}(\mathbf{H})}\right)$ or Angus $\left(\hat{\mathbf{t}}_{\mathbf{i}}+\hat{\mathbf{g}}_{\mathbf{i j}(\mathbf{A})}\right)$ cows. Also, the average of predicted breeding values was calculated when sires would be mated equally to Hereford and Angus cows. Product-moment (Pearson) and rank (Spearman) correlations of predicted breeding values for Models I and II were calculated for each sire breed and across breeds.

To quantify the effect of ignoring heterogeneity of variances on breeding values of selected bulls, sires were first ranked based on the three predicted breeding values for BWT, WW, and YW under each model; then, the mean breeding values of the top $20 \%$ sires for each ranking were calculated from evaluations with Model II. Finally, differences between mean predicted breeding values of sires selected with Models I and II were calculated. The differences in mean predicted breeding values also were calculated for the $5,10,15$, and $20 \%$ of sires selected based on acrossbreeds ranking.

Expectations of solutions for breed group of sire effects and for HET effects are the same for these two models. As an example, expectations of solutions when sires were mated to Hereford cows were as follows: 
$E($ Angûs 1$)=$ Angus $1-$ Angus 2

$E$ (Angûs 2) $=0$

$\mathrm{E}($ Herêford 1$)=$ Hereford $1+\mathrm{FC}$

$E($ Herêford 2) $=$ Hereford $2+F C$

$E($ Polled Herêford 1$)=$ Polled Hereford $1+F C$

$E($ Polled Herêford 2) $=$ Polled Hereford $2+F C$

$E($ Charôlais 1$)=$ Charolais 1 - Angus 2

$\mathrm{E}($ Charôlais 2) $=$ Charolais 2 - Angus 2

$\mathrm{E}($ Simmêntal $)=$ Simmental - Angus 2

$\mathrm{E}($ Limoûsin $)=$ Limousin - Angus 2

$\mathrm{E}($ Salêrs $)=$ Salers - Angus 2

$\mathrm{E}(\mathrm{H} \hat{\mathrm{E} T})=\mathrm{HET}+$ Angus $2+\mathrm{FC}$,

where FC are the fixed-effect levels for which constraints were assigned to make full rank the LHS of the mixed-model equations. Linear functions of the solutions were obtained such that every sire-breedgroup effect was confounded with similar effects so that differences were estimable. Because purebred performance is not associated with heterosis effects, an estimate of individual heterosis for Hereford and Angus crosses $\left(\mathbf{h}_{\mathbf{H A}}\right)$, obtained from these data, was added to purebred matings to adjust performance to $\mathrm{F}_{1}$ basis. Then,

$\mathrm{E}$ (Angûs $1+\mathrm{H} \hat{\mathrm{E} T})=$ Angus $1+\mathrm{HET}+\mathrm{FC}$ $\mathrm{E}$ (Angûs $2+\mathrm{H} \hat{\mathrm{E} T})=$ Angus $2+\mathrm{HET}+\mathrm{FC}$ $E\left(\right.$ Herêford $\left.1+\hat{h}_{H_{A}}\right)=$ Hereford $1+h_{H A}+F C$ $\mathrm{E}($ Simmêntal $+\mathrm{HET})=$ Simmental $+\mathrm{HET}+\mathrm{FC}$,

and so, differences between these expectations estimate breed group of sire differences. An implicit assumption is a common heterosis effect among Bos taurus crosses (Cundiff et al., 1986), equivalent to $\mathrm{h}_{\mathrm{HA}}$.

\section{Results and Discussion}

Correlations. Product-moment and rank correlations between predicted breeding values of sires from models with and without heterogeneous variances for BWT, WW, and YW are shown in Table 4. These estimates were calculated for predictions of sires when used on Hereford or Angus or equally on Hereford and Angus cows.

Estimates of product-moment and rank correlations across breeds of predicted breeding values with and without accounting for heterogeneous variances were approximately one for BWT and WW regardless of the maternal environment. However, these correlations were smaller for $\mathrm{YW}$ than for the other traits and smaller for Hereford than for Angus maternal environments. No difference was observed between productmoment and rank correlations of breeding values across breeds, but larger differences were observed when these correlations were calculated by breed of sire.

Generally, rank correlations estimated by breed of sire tended to be smaller than product-moment correlations. No particular pattern was expected in comparing these correlations, because of their nature, except that rank correlations are likely to be more variable and less precise for traits that are normally distributed. For example, for observations around the mean, rank changes occur quite easily relative to magnitude of differences on the normal scale. Productmoment correlations assume bivariate normal (joint) distribution of random variables (Gill, 1978), in this case predicted breeding values, and quantify the degree of linear association between predictions from Models I and II. Conversely, rank correlations measure the degree of association of ranks of predicted breeding values of sires from both models.

Correlations within sire breeds were generally smaller than those calculated across breeds, which is expected because correlations are highly dependent on the range of variables sampled (Gill, 1978). Rank correlations for BWT calculated when sires were to be used equally in Hereford and Angus cows were relatively large for most sire breeds, except for Limousin (.78), Tarentaise (-.07), and Salers (.72). Correlations for WW tended to be smaller than for BWT. For YW, correlations were even smaller, and more variation in correlations was observed across sire breeds.

For a more objective criterion to measure the effect of adjusting for heterogeneous variances on selection response, sires were ranked on the basis of predictions separately for Models I and II, and then the mean of predicted breeding values of selected sires under Model II was calculated. The difference in these predictions of genetic means is the expected genetic loss, if selection of sires is made ignoring heterogeneity of variances across sire breeds.

Prediction of Breeding Values Within Breeds. Table 5 shows differences in mean predicted genetic values of top $20 \%$ sires selected within each breed based on models with and without accounting for heterogeneous variances, for BWT, WW, and YW, and when sires are mated to Hereford, Angus, or equally to Hereford and Angus cows. These differences agree well with the correlations. Generally, the larger differences in mean genetic values were found when estimates of correlations were smaller. For BWT small differences were observed, except for Tarentaise, for which correlations were also low. Practically the same Polled Hereford and Charolais sires were selected under either model.

For WW, the differences tended to be somewhat larger than for BWT and were similar for all sire breeds except Angus. Differences were largest for Angus sires when used equally on Hereford and Angus cows and smallest for Tarentaise, where exactly the 
Table 4. Product-moment (P) and rank (R) correlations between predicted breeding values from models with and without adjusting for heterogeneous variances when sires were mated to Hereford (HH), Angus (AA), or equally to Hereford and Angus cows (H\&A) for weights at birth (BWT), 200 days (WW), and 365 days (YW)

\begin{tabular}{|c|c|c|c|c|c|c|c|c|c|c|c|c|c|c|c|c|c|c|}
\hline \multirow[b]{3}{*}{ Breed } & \multicolumn{6}{|c|}{ BWT } & \multicolumn{6}{|c|}{ WW } & \multicolumn{6}{|c|}{ YW } \\
\hline & \multicolumn{2}{|c|}{$\mathrm{HH}$} & \multicolumn{2}{|c|}{ AA } & \multicolumn{2}{|c|}{$H \& A$} & \multicolumn{2}{|c|}{$\mathrm{HH}$} & \multicolumn{2}{|c|}{ AA } & \multicolumn{2}{|c|}{$H \& A$} & \multicolumn{2}{|c|}{$\mathrm{HH}$} & \multicolumn{2}{|c|}{ AA } & \multicolumn{2}{|c|}{$H \& A$} \\
\hline & $P$ & $\mathrm{R}$ & $\mathrm{P}$ & $\mathrm{R}$ & $P$ & $\mathrm{R}$ & $\mathrm{P}$ & $\mathrm{R}$ & $P$ & $\mathrm{R}$ & $P$ & $\mathrm{R}$ & $\mathrm{P}$ & $\mathrm{R}$ & $P$ & $\mathrm{R}$ & $P$ & $\mathrm{R}$ \\
\hline Angus & .97 & .97 & .96 & .96 & .97 & .97 & .92 & .93 & .93 & .94 & .81 & .82 & .84 & .83 & .91 & .91 & .88 & .87 \\
\hline Hereford & .95 & .94 & .95 & .94 & .95 & .95 & .95 & .92 & .93 & .89 & .95 & .93 & .80 & .76 & .87 & .86 & .85 & .83 \\
\hline Polled Hereford & .89 & .85 & .96 & .97 & .96 & .96 & .98 & .94 & .96 & .93 & .98 & .90 & .94 & .90 & .97 & .95 & .96 & .92 \\
\hline Charolais & .94 & .93 & .94 & .94 & .94 & .93 & .93 & .92 & .94 & .94 & .93 & .93 & .78 & .75 & .83 & .82 & .82 & .81 \\
\hline Shorthorn & .86 & .88 & .84 & .85 & .90 & .93 & .88 & .85 & .88 & .85 & .89 & .89 & .52 & .57 & .61 & .69 & .57 & .61 \\
\hline Simmental & .88 & .88 & .91 & .92 & .90 & .91 & .95 & .94 & .94 & .91 & .95 & .92 & .71 & .53 & .78 & .69 & .74 & .63 \\
\hline Limousin & .91 & .73 & .89 & .77 & .90 & .78 & .93 & .86 & .97 & .91 & .96 & .92 & .53 & .53 & .57 & .64 & .54 & .53 \\
\hline Maine-Anjou & .91 & .75 & .96 & .92 & .96 & .95 & .96 & .92 & .91 & .92 & .96 & .93 & .05 & .01 & .65 & .61 & .17 & .16 \\
\hline Chianina & .94 & .94 & .95 & .95 & .95 & .94 & .93 & .94 & .94 & .92 & .94 & .93 & .75 & .84 & .77 & .90 & .77 & .89 \\
\hline Gelbvieh & .98 & .98 & .98 & .98 & .98 & .98 & .88 & .84 & .84 & .78 & .88 & .83 & .75 & .78 & .82 & .85 & .79 & .84 \\
\hline Tarentaise & .28 & .32 & -.05 & -.04 & .11 & -.07 & .87 & .54 & .98 & .86 & .94 & .89 & .72 & .68 & .90 & .96 & .77 & .64 \\
\hline Salers & .75 & .73 & .68 & .59 & .76 & .72 & .82 & .64 & .76 & .62 & .80 & .64 & .72 & .77 & .82 & .79 & .77 & .79 \\
\hline Across breeds & .97 & .96 & .97 & .96 & .97 & .97 & .94 & .94 & .96 & .96 & .94 & .94 & .85 & .84 & .90 & .90 & .89 & .88 \\
\hline
\end{tabular}

same sires were selected. For all other sire breeds, differences on expected mean breeding values generally varied from .4 to $2.0 \mathrm{~kg}$.

For $Y W$, differences in mean genetic values were even larger than for WW, except for Chianina and Tarentaise, for which basically the same sires were selected with both models. These differences generally ranged from 3 to $20 \mathrm{~kg}$ for the various sire breeds and maternal environments.

Prediction of Breeding Values Across Breeds. The procedure used for the analysis of data in this study allows comparisons of predicted breeding values across breeds. Differences of mean predicted genetic values from models with and without adjusting for heterogeneous variances for various proportions of selected sires across breeds are shown in Table 6 .

Differences in predicted genetic values of sires for BWT were approximately the same regardless of the proportion selected. However, those differences were predicted to be larger (.1 $\mathrm{kg}$ approximately) for matings to Hereford rather than to Angus cows.

For WW, predicted differences in genetic values of selected sires tended to decrease as the proportion of selected sires increased. These differences tended to be larger (.5 kg approximately) when sires were mated to Hereford rather than to Angus cows. Differences in genetic values of selected sires increased as intensity of selection also increased for YW. These differences were larger ( $3 \mathrm{~kg}$ approximately) when sires were mated to Hereford rather than to Angus cows. For YW, large differences in genetic values of selected sires were observed, ranging from 6 to $16 \mathrm{~kg}$ for various maternal environments and proportions of sires selected, in agreement with the smaller correlations. As the level of heterogeneity among the (co)variance components across sire breeds increases,

Table 5. Differences in mean predicted breeding values $(\mathrm{kg})$ of top $20 \%$ sires selected within each breed based on models with and without accounting for heterogeneous variances when sires were mated to Hereford (HH), Angus (AA), or equally to Hereford and Angus cows (H\&A) for weights at birth (BWT), 200 days (WW), and 365 days (YW)

\begin{tabular}{|c|c|c|c|c|c|c|c|c|c|}
\hline \multirow[b]{2}{*}{ Breed } & \multicolumn{3}{|c|}{ BWT } & \multicolumn{3}{|c|}{ WW } & \multicolumn{3}{|c|}{ YW } \\
\hline & $\mathrm{HH}$ & AA & $H \& A$ & $\mathrm{HH}$ & AA & $H \& A$ & $\mathrm{HH}$ & AA & $H \& A$ \\
\hline Angus & .16 & .20 & .17 & 1.49 & 1.85 & 4.80 & 7.40 & 3.19 & 4.84 \\
\hline Hereford & .12 & .29 & .18 & .00 & 1.04 & .38 & 5.19 & 3.32 & 7.98 \\
\hline Polled Hereford & .00 & .00 & .00 & 1.65 & .16 & 1.29 & 3.79 & 5.15 & 5.68 \\
\hline Charolais & .01 & .01 & .00 & .69 & .12 & .43 & 4.58 & 6.32 & 3.76 \\
\hline Shorthorn & .49 & .40 & .09 & 1.73 & 1.22 & 1.21 & 10.14 & 8.36 & 9.25 \\
\hline Simmental & .50 & .67 & .58 & 1.39 & 1.16 & .89 & 6.71 & 4.19 & 4.90 \\
\hline Limousin & .22 & .20 & .30 & .12 & .94 & 1.38 & 16.66 & 13.51 & 13.03 \\
\hline Maine-Anjou & .55 & .32 & .10 & 1.06 & .00 & .37 & 20.09 & 4.30 & 10.23 \\
\hline Chianina & .37 & .36 & .36 & .00 & .46 & .51 & .01 & .00 & .00 \\
\hline Gelbvieh & .03 & .13 & .08 & .52 & 2.03 & .59 & 15.58 & 19.03 & 13.25 \\
\hline Tarentaise & 6.21 & .25 & 2.45 & .00 & .00 & .00 & .00 & .00 & 2.27 \\
\hline Salers & .06 & .07 & .04 & 1.94 & 2.12 & 1.73 & 5.95 & 3.30 & 5.28 \\
\hline
\end{tabular}


Table 6. Differences in mean predicted breeding values $(\mathrm{kg})$ of sires across breeds selected based on models with and without accounting for heterogeneous variances for various proportions selected (\%) when sires were mated to Hereford ( $\mathrm{HH})$, Angus (AA), or equally to Hereford and Angus cows (H\&A) for weights at birth (BWT), 200 days (WW), and 365 days (YW)

\begin{tabular}{|c|c|c|c|c|c|c|c|c|c|}
\hline \multirow[b]{2}{*}{$\%$} & \multicolumn{3}{|c|}{ BWT } & \multicolumn{3}{|c|}{ WW } & \multicolumn{3}{|c|}{$\mathrm{YW}$} \\
\hline & $\mathrm{HH}$ & AA & $H \& A$ & $\mathrm{HH}$ & AA & $\mathrm{H} \& A$ & $\mathrm{HH}$ & AA & $H \& A$ \\
\hline 5 & .26 & .17 & .15 & 2.08 & 2.31 & 1.60 & 16.23 & 11.27 & 9.33 \\
\hline 10 & .25 & .12 & .16 & 1.43 & 1.00 & 1.31 & 10.25 & 8.43 & 8.88 \\
\hline 15 & .34 & .18 & .22 & 1.33 & .52 & .69 & 10.10 & 7.40 & 8.29 \\
\hline 20 & .31 & .19 & .16 & 1.36 & .34 & .33 & 8.59 & 5.74 & 6.04 \\
\hline
\end{tabular}

larger differences in Table 6 are expected. Therefore, even when no statistical test for heterogeneity was done, there are indications that (co)variance components were more heterogeneous for YW than for WW (Tables 2 and 3).

These results indicate that, if Model II is the true model, half of the differences in predicted genetic means of selected bulls shown in Table 6 would be gained in the following calf crop.

Breed of Sire Effects. Estimates of breed of sire effects, as deviations from Angus, when sires are to be equally used on Hereford and Angus cows, are presented in Table 7 for BWT, WW, and YW.

Breed of sire effects for BWT were approximately the same size for models with and without heterogeneous variances, except for Tarentaise. Similar results were observed for WW. For YW, however, larger differences in breed of sire effects were observed between the two models, mainly for Tarentaise (11.1 $\mathrm{kg})$, Simmental $(9.9 \mathrm{~kg})$, Limousin $(6.6 \mathrm{~kg})$, Shorthorn $(4.3 \mathrm{~kg})$, and Salers $(3.9 \mathrm{~kg})$.

Standard errors of breed of sire effects for BWT, WW, and YW calculated from models with and without accounting for heterogeneous variances are also shown in Table 7. Standard errors accounting for heterogeneous variances were larger than those when heterogeneity was ignored. These standard errors were calculated incorrectly deliberately (because of programming restrictions). This can be explained using a simple model as follows:

Let Model II be $\mathrm{y}=\mathrm{Xb}+\mathrm{e}$ with $\operatorname{Var}(\mathrm{y})=\mathrm{V}$ and this is the true model, and let Model I be $\mathrm{y}=\mathrm{Xb}+\mathrm{e}$ with $\operatorname{Var}(\mathrm{y})=\mathrm{M}$ where $\mathrm{M}$.ne. $\mathrm{V}$. The solutions are:

$$
\begin{aligned}
& \hat{b}_{\mid I}=\left(X^{\prime} V^{-1} X\right)^{-}\left(X^{\prime} V^{-1} y\right) \text { and } \\
& \hat{b}_{\mid}=\left(X^{\prime} M^{-1} X\right)^{-}\left(X^{\prime} M^{-1} y\right)
\end{aligned}
$$

Then, error variances are:

$$
\begin{aligned}
& \operatorname{Var}\left(\hat{b}_{\mid 1}\right)=\left(X^{\prime} \mathbf{V}^{-1} X\right)^{-} \text {and } \\
& \operatorname{Var}\left(\hat{b}_{\mid}\right)=\left(X^{\prime} M^{-1} X\right)^{-} X^{\prime} M^{-1} V^{-1} M^{-1}\left(X^{\prime} M^{-1} X\right)^{-} .
\end{aligned}
$$

However, $\operatorname{Var}\left(\hat{\mathrm{b}}_{\mathrm{I}}\right)=\left(\mathrm{X}^{\prime} \mathrm{M}^{-1} \mathrm{X}\right)^{-}$was used in this study.

Thus, standard errors for the homogeneous variance model were forced to be smaller than those for the heterogeneous variance model.

General. The presence of heterogeneous variances across herds or milk production levels has been reported in dairy cattle (e.g., Van Vleck and Bradford, 1964; Boldman and Freeman, 1990). Different alternatives have been proposed to account for heterogeneous variances, ranging from ignoring heterogeneity,

\begin{tabular}{|c|c|c|c|c|c|c|}
\hline Breed & HV & AV & HV & AV & HV & AV \\
\hline Hereford & $1.01 \pm .40$ & $.88 \pm .37$ & $-2.20 \pm 1.98$ & $-2.41 \pm 1.81$ & $-7.13 \pm 3.24$ & $-6.64 \pm 2.72$ \\
\hline Polled Hereford & $1.90 \pm .58$ & $1.81 \pm .53$ & $7.08 \pm 2.99$ & $6.90 \pm 2.57$ & $8.35 \pm 4.39$ & $5.00 \pm 3.84$ \\
\hline Charolais & $4.24 \pm .43$ & $4.28 \pm .38$ & $10.42 \pm 2.30$ & $10.17 \pm 1.91$ & $19.88 \pm 3.41$ & $18.46 \pm 2.81$ \\
\hline Shorthorn & $3.26 \pm .60$ & $3.18 \pm .51$ & $10.44 \pm 3.12$ & $12.27 \pm 2.53$ & $23.10 \pm 4.15$ & $18.85 \pm 3.72$ \\
\hline Simmental & $3.70 \pm .50$ & $3.48 \pm .49$ & $8.92 \pm 2.62$ & $8.16 \pm 2.47$ & $-1.07 \pm 4.07$ & $8.87 \pm 3.68$ \\
\hline Chianina & $4.75 \pm .66$ & $4.80 \pm .55$ & $10.25 \pm 3.14$ & $10.01 \pm 2.72$ & $9.67 \pm 4.20$ & $11.24 \pm 4.02$ \\
\hline Gelbvieh & $3.08 \pm .56$ & $3.07 \pm .48$ & $10.22 \pm 2.54$ & $10.86 \pm 2.35$ & $13.04 \pm 4.31$ & $-12.66 \pm 3.47$ \\
\hline Tarentaise & $3.17 \pm 1.30$ & $1.59 \pm .80$ & $2.93 \pm 4.55$ & $2.04 \pm 3.89$ & $-18.72 \pm 4.89$ & $-7.65 \pm 5.89$ \\
\hline Salers & $2.43 \pm .45$ & $2.22 \pm .51$ & $9.88 \pm 3.18$ & $8.76 \pm 2.54$ & $16.09 \pm 4.23$ & $12.15 \pm 3.72$ \\
\hline
\end{tabular}

Table 7. Estimates of breed of sire effects, as deviations from Angus, from models with (HV) and without (AV) adjusting for heterogeneous variances for weights at birth (BWT), 200 days (WW), and 365 days (YW) when sires were mated equally to Hereford and Angus cows 
through transformation and standardization of records, to use of multiplicative mixed models or of multiple-trait models (Hill, 1984; Gianola, 1986; Van Vleck, 1987; Visscher et al., 1991; Kachman and Everett, 1993). The consensus is that, if variance and covariance components are known, the best approach to adjust for heterogeneous variances is to consider the expression of a genotype in different environments to be different traits (Falconer, 1952; Henderson, 1984; Gianola, 1986; Van Vleck, 1987). Under these circumstances, and having the correct model, use of mixedmodel procedures will result in BLUE (Henderson et al., 1959) of fixed effects and in BLUP (Henderson, 1963) of random effects. Because (co)variances and the true model are never known, in this study estimates of the population parameters were used to set up the mixed-model equations, and the heterogeneous variance model was assumed to be closer to the true model; thus, solutions for fixed and random effects are approximations to BLUE and BLUP, respectively.

Effects of adjusting for heterogeneous variances on predicted breeding values, measured through correlations or mean predicted genetic values of selected sires, were small for BWT, intermediate for WW, and larger for YW. Sizable effects of adjusting for heterogeneous variances (ranging from 6 to $16 \mathrm{~kg}$ ) were observed for YW on predicted breeding values of selected sires across breeds. The potential implication of these results is for comparison of sires across different breeds for crossbreeding in commercial beef cattle production systems. If sires are selected based on models accounting for heterogeneous variances,

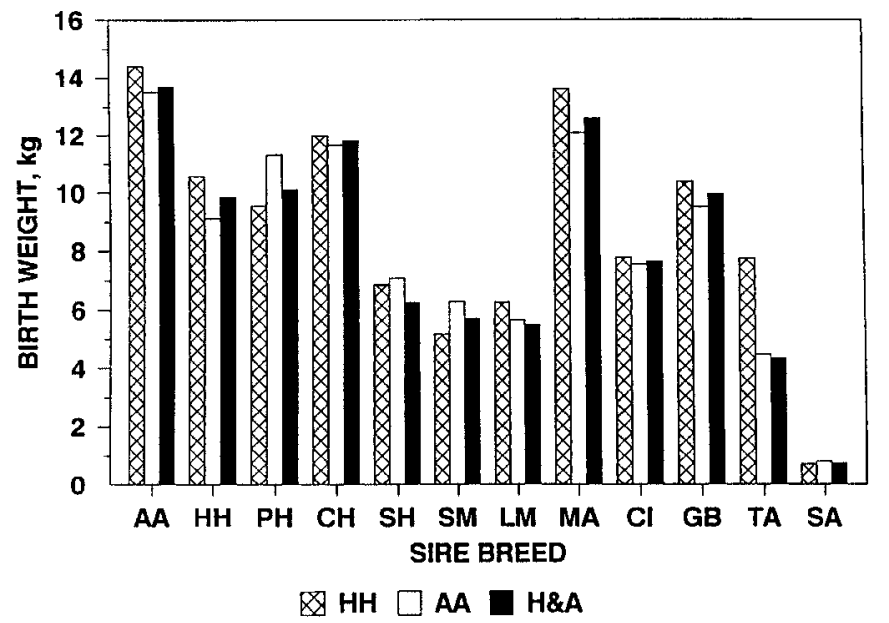

Figure 1. Ranges in predicted breeding values of Angus (AA), Hereford ( $\mathrm{HH})$, Polled Hereford (PH), Charolais $(\mathrm{CH})$, Shorthorn $(\mathrm{SH})$, Simmental (SM), Limousin (LM), Maine-Anjou (MA), Chianina (CI), Gelbvieh (GB), Tarentaise (TA), and Salers (SA) sires from models accounting for heterogeneous variances when sires are used on $\mathrm{HH}, \mathrm{AA}$, or equally on $\mathrm{HH}$ and AA (H\&A) cows for birth weight.

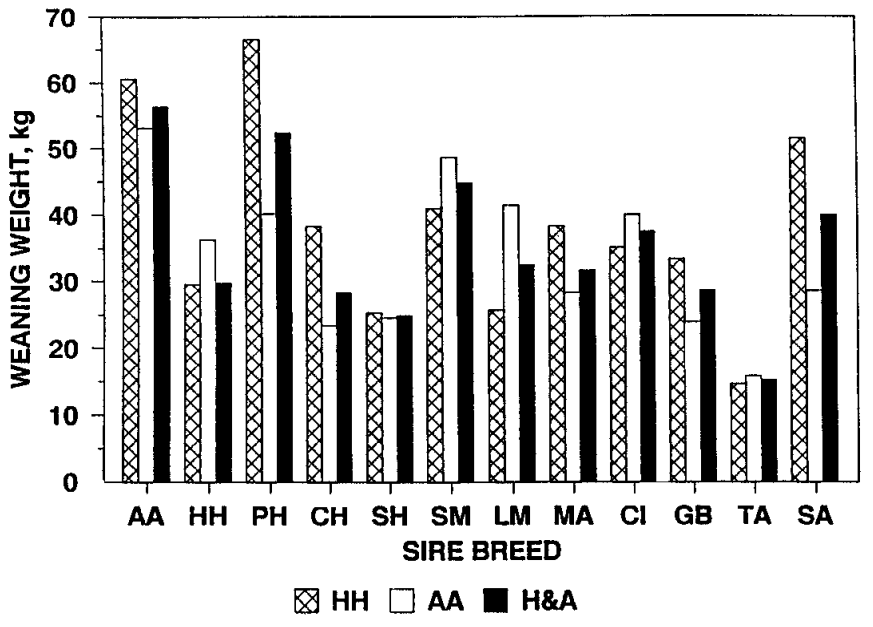

Figure 2. Ranges in predicted breeding values of Angus (AA), Hereford (HH), Polled Hereford (PH), Charolais (CH), Shorthorn (SH), Simmental (SM), Limousin (LM), Maine-Anjou (MA), Chianina (CI), Gelbvieh (GB), Tarentaise (TA), and Salers (SA) sires from models accounting for heterogeneous variances when sires are used on $\mathrm{HH}, \mathrm{AA}$, or equally on $\mathrm{HH}$ and AA (H\&A) cows for 200-d weight.

results from this study suggest that one-half of the differences presented in Table 6 can be gained in the following calf crop.

Variation on predictions of breeding values across breeds from these analyses includes both within- and among-breed genetic variability. Figures 1,2 , and 3

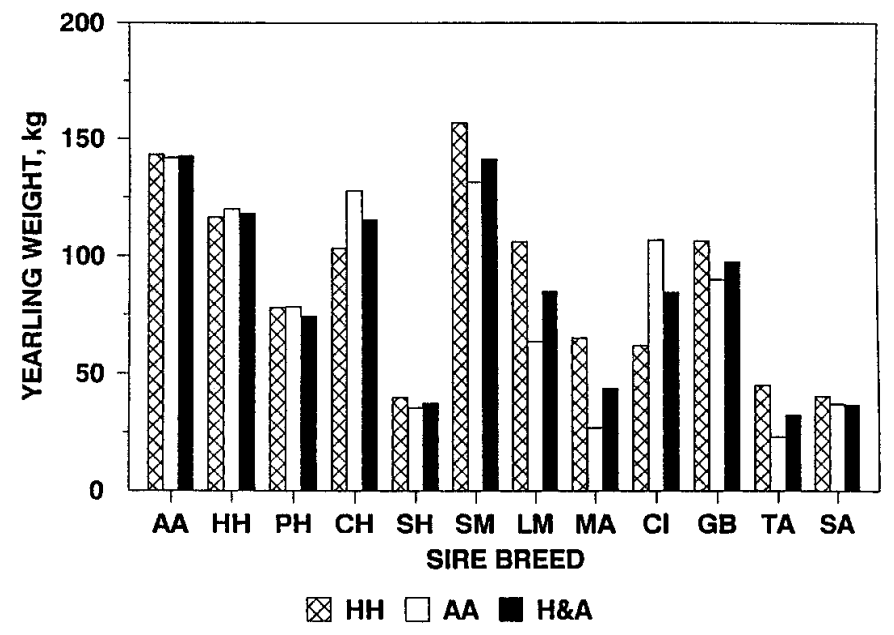

Figure 3. Ranges in predicted breeding values of Angus (AA), Hereford ( $\mathrm{HH})$, Polled Hereford (PH), Charolais (CH), Shorthorn (SH), Simmental (SM), Limousin (LM), Maine-Anjou (MA), Chianina (CI), Gelbvieh (GB), Tarentaise (TA), and Salers (SA) sires from models accounting for heterogeneous variances when sires are used on $\mathrm{HH}, \mathrm{AA}$, or equally on $\mathrm{HH}$ and AA (H\&A) cows for 365-d weight. 


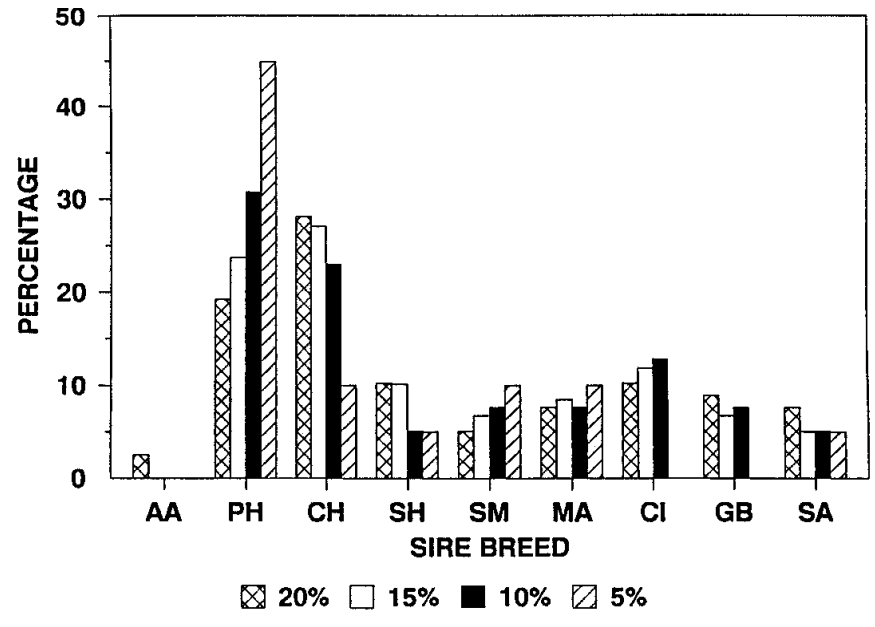

Figure 4. Percentages of Angus (AA), Polled Hereford $(\mathrm{PH})$, Charolais $(\mathrm{CH})$, Shorthorn $(\mathrm{SH})$, Simmental $(\mathrm{SM})$, Maine-Anjou (MA), Chianina (CI), Gelbvieh (GB), and Salers (SA) sires that are selected for 200-d weight at various selection intensities based on an across-breed ranking of predicted breeding values.

show within-breed ranges of predicted breeding values of sires from models with heterogeneous variances, for BWT, WW, and YW, respectively, when sires were to be used on Hereford, Angus, or equally on Hereford and Angus cows. These ranges are greatly influenced by the sample of sires used in this experiment but give an idea of within-breed genetic differences. Ranges in predicted breeding values differed by breed of sire. Ranges in predicted breeding values within sire breeds were averaged across breeds when sires were to be used on Hereford, Angus, or equally on Hereford and Angus cows, and were, respectively, 8.8, 8.3, and 8.2 $\mathrm{kg}$ for BWT, 38.4, 33.8, and $35.3 \mathrm{~kg}$ for $\mathrm{WW}$, and 88.8, 82.0, and $84.3 \mathrm{~kg}$ for $\mathrm{YW}$. Ranges in predicted breeding values varied depending on the maternal environment in which their progeny were raised, mainly for WW and YW.

Because performance data were recorded on calves out of several sire breeds mated to common dam breeds, breed of sire differences estimate only half of the direct breed effects. Thus, breed effects were calculated as twice the breed of sire effects. Ranges in breed effects when sires were to be used on Hereford, Angus, or equally on Hereford and Angus cows were, respectively, 10.4, 11.0, and $10.7 \mathrm{~kg}$ for BWT, 27.8, 30.9 , and $25.3 \mathrm{~kg}$ for $\mathrm{WW}$, and $114.1,79.4$, and $83.6 \mathrm{~kg}$ for $\mathrm{YW}$.

Breed group effects and deviations due to direct genetic effects are combined when obtaining predictions of genetic values in these analyses. Ranges in predicted breeding values across breeds when sires were to be used on Hereford, Angus, or equally on Hereford and Angus cows were, respectively, 25.7, 24.8, and $25.0 \mathrm{~kg}$ for BWT, 86.1, 71.1, and $73.4 \mathrm{~kg}$ for
WW, and 203.9, 193.3, and $184.4 \mathrm{~kg}$ for YW. These results agree with previous reports indicating that the range in breed differences is of similar magnitude to that for breeding values of individual animals within a sire-breed type (Cundiff et al., 1986).

Potential problems associated with the possibility of comparing sires across breeds have been discussed by Van Vleck (1989). One of these problems relates to the number of traits that need to be evaluated in order to make fair comparisons of sires among breeds. This is illustrated in Figures 4 and 5 . Those figures show the percentage of sires from a breed that would be selected based on an across-breed ranking of predicted breeding values from models with heterogeneous variances, for WW and YW and for various selection intensities. Only breeds with selected sires are shown in these figures. Obviously, if only growth traits, such as WW and $Y W$, are the selection criteria, sires from only a few breeds would be chosen. F or example, if YW is the selection criterion, 40 to $70 \%$ of the bulls selected across breeds would be Charolais, depending on the intensity of selection applied. Therefore, continuing efforts to provide genetic evaluations for additional economically important traits are required for fair comparison of sires across breeds to increase efficiency in particular production environments. An additional problem is that errors of estimating sirebreed effects are repeated every time these effects are used to estimate those breeding values ( $\mathrm{N}$ úñezDominguez et al., 1993b). Then, every animal in a breed can falsely benefit from a favorable error and every animal in another breed can be handicapped by an unfavorable error in estimation of sire-breed effects. This problem may partially explain the differences in breed of sire ranking in Figures 4 and 5 .

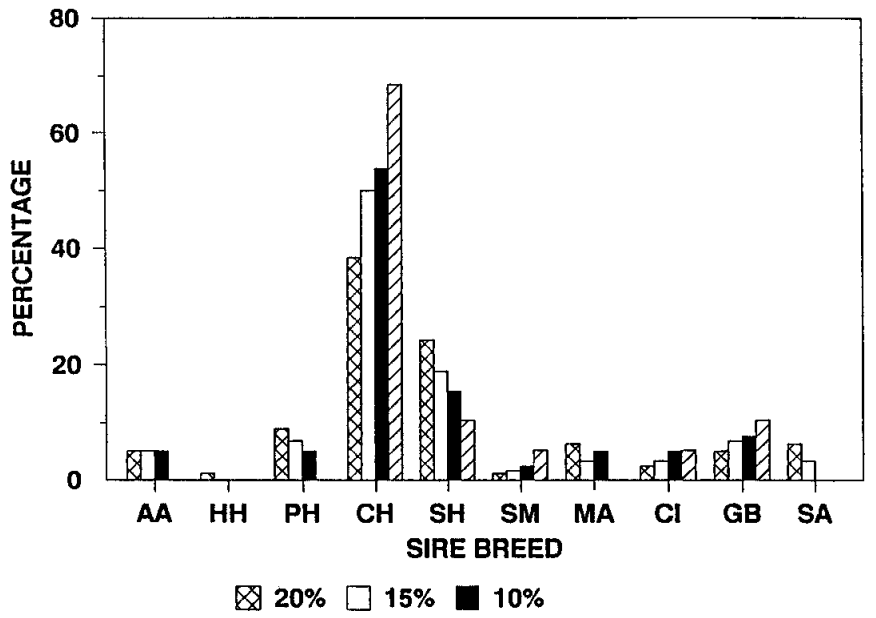

Figure 5. Percentages of Angus (AA), Hereford (HH), Polled Hereford $(\mathrm{PH})$, Charolais $(\mathrm{CH})$, Shorthorn $(\mathrm{SH})$, Simmental (SM), Maine-Anjou (MA), Chianina (CI), Gelbvieh (GB), and Salers (SA) sires that are selected for 365 -d weight at various selection intensities based on an across-breed ranking of predicted breeding values. 
Table 8. Mean predicted breeding values $(\mathrm{kg})$ of top $20 \%$ sires selected within each breed from a model accounting for heterogeneous variances when sires were mated to Hereford $(\mathrm{HH})$, or to Angus (AA) cows for weights at birth (BWT), 200 days (WW), and 365 days (YW)

\begin{tabular}{|c|c|c|c|c|c|c|}
\hline \multirow[b]{2}{*}{ Breed } & \multicolumn{2}{|c|}{ BWT } & \multicolumn{2}{|c|}{ WW } & \multicolumn{2}{|c|}{ YW } \\
\hline & $\mathrm{HH}$ & AA & $\mathrm{HH}$ & AA & $\mathrm{HH}$ & AA \\
\hline Angus & 7.36 & 6.20 & 26.42 & 24.43 & 60.49 & 52.67 \\
\hline Hereford & 8.21 & 7.05 & 11.50 & 13.96 & 41.67 & 39.87 \\
\hline Polled Hereford & 10.17 & 10.62 & 57.14 & 35.39 & 87.65 & 55.88 \\
\hline Charolais & 14.32 & 13.21 & 33.12 & 40.93 & 90.10 & 96.22 \\
\hline Shorthorn & 11.31 & 10.86 & 32.93 & 36.92 & 99.22 & 61.85 \\
\hline Simmental & 12.59 & 11.14 & 39.80 & 37.34 & 78.89 & 47.99 \\
\hline Limousin & 8.18 & 7.30 & 16.76 & 25.01 & 29.03 & 7.64 \\
\hline Maine-Anjou & 16.39 & 16.42 & 31.84 & 40.83 & 64.33 & 72.52 \\
\hline Chianina & 14.99 & 14.01 & 36.21 & 41.21 & 55.67 & 80.32 \\
\hline Gelbvieh & 12.44 & 11.37 & 33.33 & 41.99 & 76.70 & 83.08 \\
\hline Tarentaise & 12.95 & 9.49 & 21.09 & 23.95 & -2.25 & 7.30 \\
\hline Salers & 8.63 & 6.12 & 44.65 & 31.32 & 75.51 & 53.54 \\
\hline
\end{tabular}

In Núñez-Dominguez et al. (1993a), potential reranking of sires when producing progeny in different maternal environments was indicated. Thus, it is expected that sire evaluations may differ depending on the breeds of their mates. Table 8 presents means for BWT, WW, and YW of predicted breeding values of sires selected within breed (top 20\%) when mated to Hereford or Angus cows. Differences in mean genetic values of selected sires when evaluated on Hereford vs Angus cows were relatively small for BWT (except for Tarentaise), but large differences were found for WW (e.g., from 8.3 to $21.8 \mathrm{~kg}$ for Polled Hereford, Limousin, Maine-Anjou, and Salers) and YW (e.g., from 21.4 to $37.4 \mathrm{~kg}$ for Polled Hereford, Shorthorn, Simmental, Limousin, Chianina, and Salers). There fore, treating calf performance in different maternal environments as different traits seems justified, at least for WW and YW.

Similar specific heterosis effects among Bos taurus crosses has been assumed (Cundiff et al., 1986) in these analyses, because in topcross experiments, sirebreed effects are completely confounded with heterosis effects. However, differences in specific heterosis may exist if breeds differ in level of inbreeding, because heterosis can be interpreted as the recovery of inbreeding depression that has been accumulated in a breed (Dickerson, 1973). Even differences in specific heterosis of $2 \%$ to $4 \%$ of the phenotypic mean may cause considerable bias on estimates of breed effects, and therefore on predicted breeding values (Van Vleck and Núñez-Dominguez, 1991). Thus, data from which breed and heterosis effects can be separated by appropriate modeling are needed to obtain unbiased evaluations of sires across breeds.

Models for prediction of breeding values that account for heterogeneous variances across breed groups and that allow for reranking of sires evaluated in different maternal environments were used in this study. Complexity of the models can be increased by fitting random intra- and interloci interactions, provided that enough data with nonadditive relationships are available (E Izo and Famula, 1985; Arnold et al., 1992). However, a balance between completeness of the model and feasibility of doing the computations is often required, particularly when large data sets are analyzed.

\section{Implications}

Data from topcross experiments can be used to evaluate the importance of adjusting for heterogeneous variances among breed groups for prediction of breeding values. Results from this study indicate that some additional economic returns may be gained by commercial beef cattle producers if sires are chosen across breeds based on predicted genetic values computed with models accounting for heterogeneous variances. Separate predictions of breeding values for bulls to be mated to Hereford or Angus cows may be of economic benefit, especially for 200- and 365-d weights. Costs of obtaining and analyzing crossbred data should be considered.

\section{Literature Cited}

Arnold, J. W., J. K. Bertrand, and L. L. Benyshek. 1992. Animal model for genetic evaluation of multibreed data. J. Anim. Sci. 70:3322.

BIF. 1989. New technology for genetic evaluations. Proc. Beef Improvement Federation. p 57. Nashville, TN.

BIF. 1991. Genetic prediction and live animal evaluation of carcass traits. Proc. Beef Improvement Federation. p 68. San Antonio, TX.

Boldman, K. G., and A. E. Freeman. 1990. Adjustment for heterogeneity of variances by herd production level in dairy cow and sire evaluation. J. Dairy Sci. 73:503.

Boldman, K. G., L. A. Kriese, L. D. Van Vleck, and S. D. Kachman. 1993. A Manual for Use of MTDFREML. A set of Programs to Obtain Estimates of Variances and Covariances. p 120. ARS, USDA, Washington, DC. 
Cundiff, L. V., K. E. Gregory, R. M. Koch, and G. E. Dickerson. 1986. Genetic diversity among cattle breeds and its use to increase beef production efficiency in a temperate environment. Proc. 3rd World Congr. Genet. Appl. Livest. Prod. 9:271.

Cundiff, L. V., R. M. Koch, and K. E. Gregory. 1984. Characterization of biological types of cattle (Cycle III). IV. Postweaning growth and feed efficiency. J. Anim. Sci. 58:312.

Dickerson, G. E. 1973. Inbreeding and heterosis in animals. In: Proc. of the Animal Breeding and Genetics Symp. in Honor of Dr. J ay L. Lush. pp 54-77. Am. Soc. of Anim. Sci., Champaign, IL.

Elzo, M. A., and T. R. Famula. 1985. Multibreed sire evaluation procedures within a country. J. Anim. Sci. 60:942.

Falconer, D. S. 1952. The problem of environment and selection. Am. Nat. 86:293.

Garrick, D. J ., E. J . Pollak, R. L. Quaas, and L. D. Van Vleck. 1989. Variance heterogeneity in direct and maternal weight traits by sex and percent purebred for Simmental-sired calves. J. Anim. Sci. 67:2515.

George, A., J. Liu, and E. Ng. 1980. User guide for SPARSPAK: Waterloo sparse linear equations package. CS-78-30, Dept. Comput. Sci., Univ. of Waterloo, Waterloo, ON, Canada.

Gianola, D. 1986. On selection criteria and estimation of parameters when the variance is heterogeneous. Theor. Appl. Genet. 72: 671.

Gill, J . L. 1978. Design and analysis of experiments in animal and medical sciences. The Iowa State University Press, Ames.

Henderson, C. R. 1963. Selection index and expected genetic advance. In: W. D. Hanson and H. F. Robinson (E d.) Statistical Genetics and Plant Breeding. p 141. NAS-NRC, Washington, DC.

Henderson, C. R. 1984. Applications of linear models in animal breeding. Univ. of Guelph, Guelph, ON, Canada.

Henderson, C. R., O. Kempthorne, S. R. Searle, and C. M. von Krosigk. 1959. The estimation of environmental and genetic trends from records subject to culling. Biometrics 15:192.

Hill, W. G. 1984. On selection among groups with heterogeneous variance. Anim. Prod. 39:473.
Kachman, S. D., and R. W. Everett. 1993. A multiplicative mixed model when the variances are heterogeneous. J . Dairy Sci. 76: 859.

Laster, D. B., G. M. Smith, L. V. Cundiff, and K. E. Gregory. 1979. Characterization of biological types of cattle (Cycle II). II. Postweaning growth and puberty of heifers. J. Anim. Sci. 48: 500.

Massey, M. E., and L. L. Benyshek. 1981. Interactions involving sires, breed of dam and age of dam for performance characteristics in Limousin cattle. J. Anim. Sci. 53:940.

Núñez-Dominguez, R., L. D. Van Vleck, K. G. Boldman, and L. V. Cundiff. 1993a. Correlations for genetic expression for growth of calves of Hereford and Angus dams using a multivariate animal model. J. Anim. Sci. 71:2330.

Núñez-Dominguez, R., L. D. Van Vleck, and L. V. Cundiff. 1993b. Breed comparisons for growth traits adjusted for within-breed genetic trend using expected progeny differences. J . Anim. Sci. 71:1419.

Smith, G. M., D. B. Laster, and K. E. Gregory. 1976. Characterization of biological types of cattle. I. Dystocia and preweaning growth. J. Anim. Sci. 43:27.

Tilsch, K., J . Wollert, and A. Baumung. 1989. Relationships between breeding values for growth of beef sires in purebreeding and crossbreeding. Livest. Prod. Sci. 21:275.

Van Vleck, L. D. 1987. Contemporary groups for genetic evaluations. J. Dairy Sci. 70:2456.

Van Vleck, L. D. 1989. What can be learned from the dairy experience? Proc. Third Genetic Prediction Workshop. p 5. BIF, Kansas City, MO.

Van Vleck, L. D., and G. E. Bradford. 1964. Heritability of milk yield at different environmental levels. Anim. Prod. 6:285.

Van Vleck, L. D., and R. Núñez-Dominguez. 1991. Heterosis and the breed table. 23rd Meeting of the Beef Improvement Federation. p 111. San Antonio, TX.

Visscher, P. M., R. Thompson, and W. G. Hill. 1991. Estimation of genetic and environmental variances for fat yield in individual herds and an investigation into heterogeneity of variance be tween herds. Livest. Prod. Sci. 28:273. 